\title{
Discussion on Accounting Practice Teaching Based on Accounting Talent Cultivation Objective
}

\author{
Binbin Zhu \\ Sias International University \\ Zhengzhou University \\ Zhengzhou, China 451150
}

\begin{abstract}
Accounting has been the popular major and direction of colleges of secondary and higher education for many years. But how to stand out from the millions and millions of students specialized in this major has become the problem that every educator and student need to think and reflect. This paper will start from the state policies and guidelines such as cultivation objective of accounting talents as issued by Ministry of Finance, to discuss the problems of backward teaching methods, simple teaching forms and insufficient quality of teachers existing in accounting practice education and teaching in colleges, hoping to solve these problems that exist in practical education and teaching through years of teaching experience and reflection, in order to achieve the vision of self-improvement, teaching and educating, and providing suitable talents to the country and society.
\end{abstract}

Keywords-accounting talents; practice teaching; objective

\section{INTRODUCTION}

With the rapid development of modern economy, accounting plays a vital role in economic development, and this industry has been in constant development and progress. Accounting has become very popular among the economic and management subjects in recent years. The scale of accounting specialty has been expanded constantly. At present, in addition to the finance and economics colleges, almost all the comprehensive universities and the qualified colleges of science and engineering have opened up accounting specialty; how to make accounting specialty stronger is the problem to be reflected by each college and teacher, and this is also the school and the teacher's foothold.

\section{Cultivation OBJective OF AcCounting TAlents}

The Ministry of Finance formulated and issued the Medium and Long-term Talent Development Plan for Accounting Industry (2010-2020) according to the overall requirements of National Medium and Long-term Talent Development Planning Outline (2010-2020) based on serious summary of achievements and experience obtained by accounting talent construction as well as the in-depth analysis of new situation, new tasks and new challenges faced by accounting talent development at present and in the future. In this development planning, the Ministry of Finance set the strategic objectives of accounting talent development in China by 2020: to cultivate and create an accounting team with large scale, optimized structure, high quality, rich innovation and dedication, to establish the accounting talent competition advantage in China, to construct the international first-class accounting talent team, so as to lay the accounting talent base for basically achieving socialist modernization by the middle of this century.

The Fourth Session of the Twelfth National People's Congress officially released and approved The Thirteenth Five-year Plan Outline for National Economic and Social Development of the People's Republic of China. In a chapter of promoting education modernization, it clearly put forward to strengthen practice teaching. The cultivation objective of accounting talents with strong practice ability has drawn attention from a great number of colleges again, various colleges has also changed their school-running thoughts and concept, and quite a number of colleges are transforming from research-oriented colleges to practice-oriented ones. And the accounting talent cultivation objective also pays more attention to practical link than the cultivation of theoretical knowledge.

\section{CurRent Situation OF ACCOUnting Practice TEACHING}

\section{A. Backward Practice Teaching Method}

For a long time, the one-way teaching method is adopted for China's accounting education due to the influence of examoriented education. Many accounting issues can only explain the basic principle involved in them due to the large amount of data, complex processing procedure and limitation of teaching time, and the sufficient analysis is unable to be made. Moreover, because the class time is limited, so the exchange and communication regarding views on the cases between teachers and students as well as among the students is insufficient and students are unable to learn from the case. At the same time, experiments have become the pure mechanical imitation as the experiment scheme has consistency, and the data collection, experimental process as well as the solution is essentially the same without innovation. Such experiment method is too backward, and the normative and strong operational standard for experiment hasn't been established, which is unable to develop the students' ability of independent analysis, professional judgment and innovation. In addition, the stylized exercise of students to play multiple roles in the accounting practice teaching has great gap compared with 
practical operation. Students cannot be cultivated in the simulated practices in terms of basic literacy needed by different accounting roles in their real accounting work.

\section{B. Simple Practice Teaching Content}

The current simulation practice teaching of accounting specialty in colleges is mainly set for courses of accounting calculation, and the courses mainly involved in include financial accounting and cost accounting, to exercise the student's ability of account preparation, account keeping, expense account submission and calculation. The contents of practice courses are mostly based on the economic transaction of a manufacturing enterprise within a certain accounting period. And students shall complete the full set of accounting method starting from reviewing and filling the original documents, to the accounting voucher filling, account preparation and account keeping and financial statement preparation. Yet the practice training of courses such as financial management and financial analysis is rarely involved. Traditional training content is relatively simple and the training materials are old and rigid, which is only the exercise against accounting procedure, and is unable to reflect students' analysis and mastery of accounting information. Students' ability of using the financial knowledge they have learned to forecast, plan and control the enterprise's future economic activity cannot be exercised, and the processing of existing economic transaction cannot reflect the role of accounting in enterprise management flexibly. The traditional simulation method is unable to reflect the "individualized teaching" in terms of teaching. All the students are trained with the same method no matter what their level is. And students' independent exploration and innovation ability can't be displayed to the largest extent, thus it is unable to achieve ideal practical effect.

\section{Lack of Off-campus Practice Base}

Accounting is a strong operational and practical subject. Organizing students to the enterprises for training is a traditional and effective accounting practice teaching method adopted by most colleges. The 13th Five-Year Plan mentioned the production-teaching integration and school-enterprise cooperation to promote applied talent cultivation. However, there are strong resistances in off-campus practice organization, which are mainly manifested in the following three conditions.

- Due to the confidentiality of enterprise financial information as well as the limitation and instability of the operating post in each enterprise, there is no fixed and long-term cooperation relationship and contact mechanism between colleges and enterprises, accounting firms, resulting in the loss of traditional training bases.

- The practice is arranged at the time approaching graduation, which has made accounting theoretical teaching divorce from the accounting practice teaching, making students unable to solve the problems that they don't understand timely, let along the effective combination of accounting theoretical knowledge and accounting practice.
- Because various undergraduate colleges are limited by training funds, then tend to arrange a limited practice time. And enterprise training is mostly limited to sending someone to colleges to give lectures and sending students to visit companies. In the practice link, students have difficulty in coming into contact with the real economic accounting transaction of the enterprise, let alone to participate in enterprise's accounting work, learning about the whole process of accounting and financial management.

Therefore, off-campus accounting practice is merely a formality, and the intended purpose cannot be achieved, which has hindered the effective implementation of practical teaching links, and can't play the role of cultivating students' comprehensive ability and comprehensive quality.

\section{Separation of Manual and Computerized Accounting Experiment}

Today, computer technology is popularized, and if the attention is only paid to manual experiment yet ignores the computerization experiment teaching, it is difficult to cultivate the college students with overall quality. At present, most enterprises have realized the accounting computerization in whole or in part, to master relevant knowledge of accounting, computer knowledge and operation skills is the basic requirement of accounting personnel. Due to various reasons, the accounting computerization experiment teaching is a weak link in accounting teaching. Computerization teaching software is simple without sufficient investment, computerization teaching is changed into computer programming teaching, simple subject setting and input and output teaching, and imperfect computerization teaching system have made students cannot learn about the actual accounting computerization in-depth. In fact, in addition to computerization teaching, the computer simulation experiment in some schools is only a simple inputting operation. As a result, the colleges with such teaching method are completely unable to provide the talents with computerization professional level needed by the society.

\section{E. Lack of Professional Practice Talents among Teachers}

Accounting is a professional discipline pays attention to practice and application. Teachers' teaching level is directly related to students' mastery and understanding of practical knowledge. Therefore, strengthening the cultivation of practice ability of related teachers shall be the most important thing. But at present, the double qualified teachers are insufficient. The so-called "double qualified teachers" refer to: first, "double professional title", namely in addition to obtain series title of teachers, another title shall also be obtained; second is "double quality", that is, teachers shall not only have theory teaching quality, but also shall have the practice teaching quality. Teachers cannot be engaged in teaching without title certificate, which is a form to certify teachers' qualifications. Teachers engaged in accounting teaching need to have the Certificate of Accounting Profession and title certificate at national level, and they shall enrich their knowledge reserve, perfect their own theory system, and at the same time, they shall have practice ability and experience. But now, most 
college teachers are the talents with years of theoretical study and high diploma, entering into a school from another one, as a result, they have no practical ability essentially or only have insufficient practical operation ability, resulting in practice teaching to be simplified.

\section{StREngthen the ThOUght OF ACCOUnting PRACTICE TEACHING}

\section{A. Innovate Practice Teaching Methods}

We can make a bold use of flipped classroom to teach. Teachers and students can shift their role, so students hold the initiative and decision right of the practice teaching content learning, becoming the main explainer in class. At this time, teachers are no longer the performer of the cramming teaching, but they just provide guidance through the teaching at the beginning of the class, and assist students to autonomously plan the learning of courses in class and after class. Of course, students need to learn autonomously after class, which are mainly the pre-class research and analysis. As for the practice teaching content, they can be found from the video lectures, various accounting network schools and various accounting forums. Students also can discuss with their classmates and teachers, or adopt the form of written source reference as there are many books in the library. This teaching method can not only develop the students' ability of self-study, but also can improve students' ability of expression and communication, arousing students' enthusiasm and initiative. Moreover, through the exchange and communication with each student, teachers can find different learning characteristics of each student, thus to develop each student's individuality and creativity, and teach according to students' ability.

\section{B. Improve Practice Teaching Content}

The design of accounting practice teaching content shall be made with the course as carrier, which has fully reflected the cultivation objective. Accounting practice teaching content should be formulated step by step. The practice operation exercises shall be arranged for explanation of basic theory course, to conduct operational exercise of the theory content linking with practice, and lay good foundation for practice, thus to improve students' basic skills. Comprehensive practice learning can be conducted on the basis of basic practice. And the business content of multiple industries within multiple periods of business accounting shall be adopted to cultivate students' professional skills. Schools shall also introduce the latest mode of practice teaching, such as micro comprehensive accounting practice, to enrich the content for student to study knowledge about different accounting posts, to strengthen students knowledge in terms of industry and commerce, taxation, banking as well as credit and debt relations. Moreover, in order to strengthen practice teaching effect, in accounting practice course, the ERP sand table drill course shall be added. As a new teaching method, ERP sand table simulation displays enterprise operation under the influence of internal management and external environment visually using physical mold, enabling students to apply the knowledge they have acquired, including not only the financial aspects, but also the knowledge in terms of marketing, financial analysis and financial management, to the practical training. Such practice method has broken the limitation of traditional analog manual account and computerization that focus on accounting practice. It is diversified in terms of teaching form and is rich in teaching contents, which can improve students' quality and ability comprehensively.

\section{Establish the On-campus and Off-campus Base for Accounting Practice Teaching}

Cooperate with the enterprises of different types and different scales, establish multiple off-campus practice bases to perfect various practice teaching links. The establishment of off-campus practice base has laid the scientific foundation for students to contact with society, understand the society and integrate into society in advance, providing students with the opportunities to participate in the immersive actual work, to effectively improve students' professional quality and professional skills. Schools should overcome difficulties, innovate teaching mode to cooperate with the enterprises, for example, to joint participation in the research of topics within accounting field, to provide training for enterprise accounting personnel's follow-up education, to help enterprises to improve accounting personnel's quality etc., and establish the virtuous relationship of mutual trust and mutual aid with enterprises gradually, enabling the enterprises to feel that the establishment of off-campus practice base is a win-win result for school and enterprise.

While actively developing off-campus practice teaching base construction, the on-campus practice base construction shall also be strengthened. The establishment of on-campus accounting practice base is more feasible than the construction of off-campus practice base, as school has greater autonomous right and convenience to manage students. Therefore, colleges should regard on-campus accounting practice as the effective way to help test students' knowledge, improve their ability of conscious operation ability and accounting professional judgment ability.

\section{Organic Combination of Manual and Computerized Experiment}

Manual accounting experiment is the important means for students to use professional knowledge, to recognize and consolidate theoretical knowledge, and the first base practice course for students to link theory with practice, and start the practice operation. The computerized accounting experiment is the decisive factor of students' accounting computerization level. Only by mastering the manual accounting business process, can students skillfully use the experimental data generated by account preparation and statement generation as well we professional skill support in computerized accounting experiments. At the same time, computerized accounting experiment is the intelligentization of manual accounting experiment. The two complement each other, playing an irreplaceable role in students' practice in the early stages.

The manual and computerized experiments can be conducted successively or in parallel. Successive experiment, as the name implies, refers to conduct manual accounting experiment first, and then conduct the computerized 
accounting experiment. The experimental materials, from the original documents filling, accounting vouchers preparation, accounting books registration to financial statements generation, all use the same data. Parallel experiment refers to conduct the manual accounting and computerized accounting experiments simultaneously. In this case, the manual accounting experiment is closely combining with the computerized accounting experiment, enabling students to not only master the business process of accounting manual experiment, but also know well about the operation steps and principle of computerized accounting, at the same time, time is saved, efficiency is improved, making students meet the requirements of accounting talent market.

Of course, at the time of experiment, we shall not just use one kind of software to teach. Yet there are diversified computerization software, we shall display the commonly used ones to students for several times.

\section{E. Improve the Quality of Teaching Staff}

Build a team of teachers with theoretical knowledge and practical experience. Firstly, we should strengthen the cultivation of practice-based teachers. Allow and encourage teachers to work part-time outside under the premise of not affecting the teaching schedules and teaching quality, enabling teachers to combine accounting theory and accounting actual practical work through part-time job, thus to improve teachers' practice, observation and analysis ability. Arrange the teachers to participate in the training classes that improve their professional skills on a regular basis, for example, to master the operation of ERP software, and enhance their practical ability, application ability through the study. Then, encourage teachers to obtain the intermediate and senior accounting titles, Certified Public Accountant Certificate etc. besides the teacher's series title, thus to improve their knowledge level and bring the new knowledge and new concept into class through learning. Second, take initiative to establish cooperation relations with such intermediary agencies such as enterprises and accounting firms, sign up the long-term contracts, invite the qualified financial supervisors and certified public accountants from enterprises into colleges, to offer the vivid and real accounting social accounting case teaching using their rich practical experience, benefiting all teachers and students.

\section{CONCLUSION}

Accounting specialty is a specialty with high demand yet with high unemployment rate. While selecting, the employers always expect the talents to have 2-3 years' working experience and abundant practical ability. In order to meet the requirement of employers and meet the requirements of national accounting talents development objective, colleges shall pay high attention to the practice teaching for students specialized in accounting based on the long-term development vision, thus to complete the education and teaching mission smoothly through attaching importance to mentality and support from the action. Of course, in addition to schools and teachers, the most important is the students' initiative and enthusiasm. There is saying goes that "three accrues all things of the world". Students are the experimenters of this practice teaching reform.

\section{REFERENCES}

[1] Ministry of Finance of the People's Republic of China. Notice on Printing and Distributing the Medium and Long-term Talent Development Plan for Accounting Industry (2010-2020) [S] . Ministry of Finance 2010

[2] Zhang Xiuzhen et al. Reflection on Accounting Practice Teaching Reform in Application-oriented Universities [J]. Education Collection, 2010 .

[3] Zhang Baoqing, Wang Zhendong et al. Research on Current Situation of Accounting Practice Teaching and Improvement Method [J]. Journal of Shandong Institute of Commerce and Technology, 2007, (12).

[4] Jiang Lantian. Accounting Practice Teaching System Design under Application-oriented Talent Cultivation Mode [J]. Friends of Accounting, 2009, (7).

[5] Mo Shifeng et al. Discussion on Accounting Practice Teaching [J]. Contemporary Tourism (Academic Version), 2010.

[6] Song Ming et al. Application of ERP Sand-table in Accounting Professional Experimental Teaching [J]. China Township Enterprises Accounting, 2010.

[7] Liu Huijuan et al. Research and Practice on Developing Accounting Laboratory Teaching using Modern Information Technology [J]. Continue Education Research, 2008.

[8] Shi Ping et al. Reflection on Constructing Accounting Practice Teaching System [J]. Friends of Accounting, 2010. 